\title{
The Alaska Geochemical Database: v. 1.0 - Geologic Materials
}

\section{What is the AGDB?}

The Alaska Geochemical Database (AGDB) is a new, comprehensive compilation of geologic, spatial, descriptive, mineralogical, and analytical geochemical data for samples collected in Alaska and surrounding waters by the U.S. Geological Survey (USGS) from 1962 to 2009.

Data for geologic materials (rocks, minerals and mineral separates, soils, lake sediments, bulk stream sediments, and a variety of heavy-mineral concentrates) will be released as a two-sided DVD (USGS Digital Data Series DS 637 v. 1.0) in October of 2011. Future data releases will include water, organic and leachate samples.

The AGDB contains all Alaskan data from USGS legacy databases (for example, the RASS and PLUTO systems), and all results produced by USGS in-house and contract chemistry laboratories through December 2009. The database includes geochemical data resulting from the reanalysis of archived materials, such as those from the Alaska Mineral Resource Assessment (AMRAP) and National Uranium Resource Evaluation (NURE) programs, for additional elements and by newer methods. Reanalyses include samples collected statewide as part of the National Geochemical Survey, and samples from a project across the Alaska Range (data released in 2010). The AGDB also contains data for geologic materials from Alaska submitted by USGS researchers to non-USGS and non-contract labs, and a variety of other Alaskan geologic materials samples.

\section{What types of samples are included?}

\begin{aligned} & \multicolumn{2}{c}{ The Alaska Geochemical Database } \\ & v. 1.0 includes data from: \\ & \hline 264,095 unique samples of geologic materials; \\ & 108,966 rocks; \\ & 7,470 mineral separates; \\ & 92,694 bulk lake and stream sediments; \\ & 8,096 heavy-mineral concentrates; and \\ & 6,869 soils. \end{aligned}

For these geological materials, 9,667,206 individual geochemical analyses of 160 elements and chemical species by 85 different analytical methods are reported. Mineralogic identifications by optical microscopy are available for 18,138 of the heavy mineral concentrates.

\section{Quality Control}

Data in the AGDB have undergone extensive quality control screening including searching field notes and maps for accurate location information, verifying media and sample type, linking analytical data to geologic parameters recorded by the submitter, and documenting sample preparation and analytical methods.

\section{Data Files}

The AGDB v. 1.0 two-sided DVD includes:

- a 4.3 GB Microsoft Access ${ }^{\circledR} 2007$ relational database (as two linked .mdb files);

- the same database in Microsoft Access ${ }^{\circledR} 2003$;

- Microsoft Excel ${ }^{\circledR}$ spreadsheet tables (.xls files) and ASCII text files that display the results of common queries to the database (for example, Ag-Cr values for concentrate samples; rock samples by quadrangle);

- references for analytical methods;

- references to published data; and

- metadata in three file formats. 


\section{Data Availability}

- The Alaska Geochemical Database will be available in a searchable, spatially referenced, online format at $h t t p: / /$ mrdata.usgs.gov/; estimated availability early 2012

- A 2012 update (AGDB v. 2.0) will include water, organic, leachate, and miscellaneous sample media.

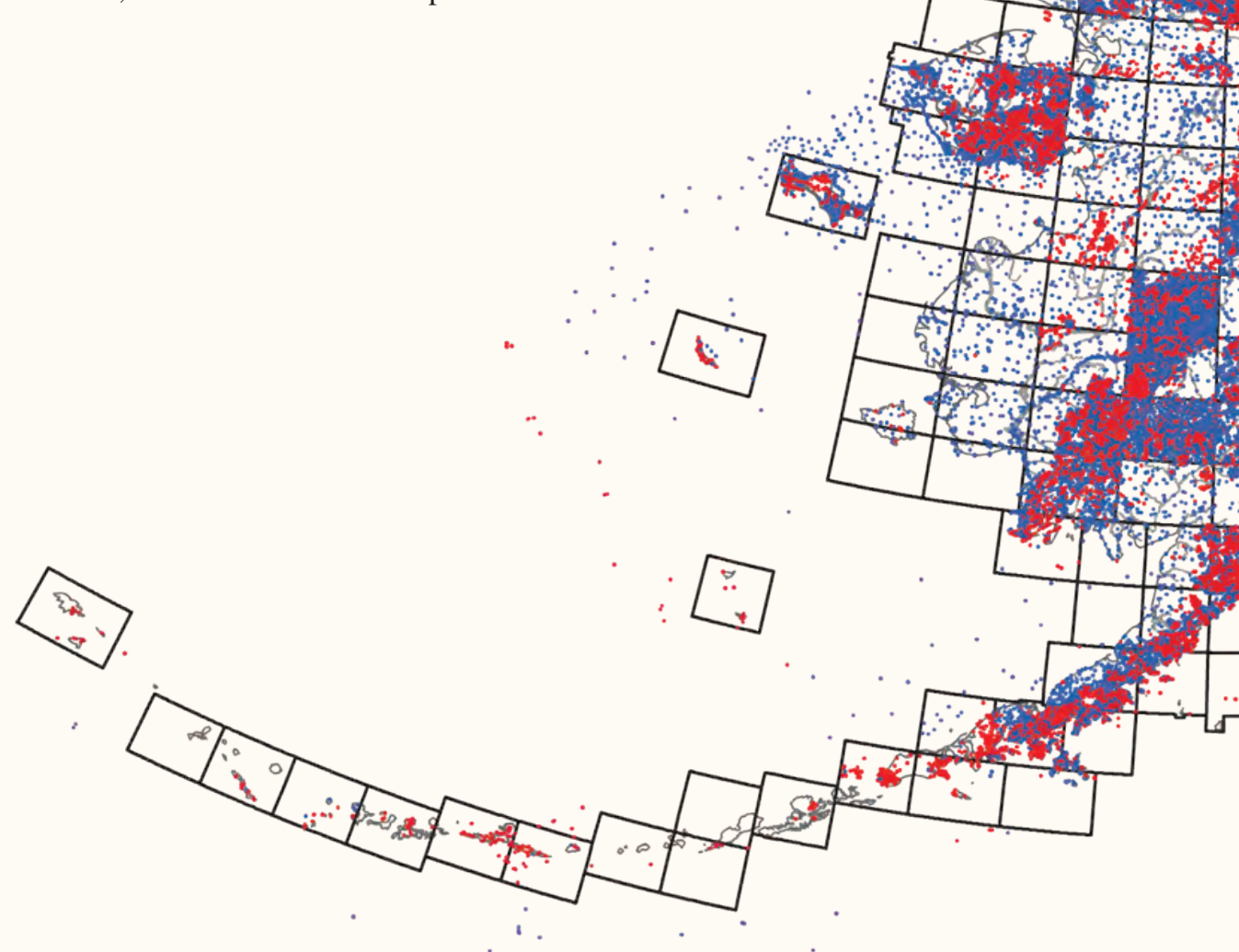

\section{For More Information}

On sample media or analytical methods:

http://minerals.cr.usgs.gov/projects/analytical_chem/references.html

Text prepared by Jeanine M. Schmidt and Matt Granitto Figure prepared by Nora Shew; Layout by Jeanine Schmidt Artwork on page 1 by Daniel Granitto (used by permission)
Map of Alaska (AK) showing the

localities of rock and mineral samples (in blue), overprinted by sediment, soil, and bulk- and processed-concentrate samples (in red) included in v. 1.0 of the AK Geochemical Database. In areas of dense sampling, red dots obscure underlying rock and mineral samples.

The USGS Mineral Resources Program is the sole Federa provider of research and information on nonfuel mineral resources.

For more information, please contact:

Mineral Resources Program Coordinator,

U.S. Geological Survey

913 National Center

Reston VA 20192

Telephone: 703-648-6100

Fax: 703-648-6057

E-mail:minerals@usgs.gov

Home page: http://minerals.usgs.gov 